Uralic studies, languages, and researchers

Edited by Sándor Szeverényi 
Studia uralo-altaica 54

Redigunt:

Katalin Sipőcz

András Róna-Tas

István Zimonyi 
Uralic studies, languages, and researchers

Proceedings of the $5^{\text {th }}$ Mikola Conference 19-20, September 2019

Edited by Sándor Szeverényi

Szeged, 2021 
(C) University of Szeged,

Department of Altaic Studies,

Department of Finno-Ugrian Philology

All rights reserved. No part of this book may be reproduced, stored in a retrieval system, or transmitted in any form or by other means, electronic, mechanical, photocopying, recording or otherwise, without the prior permission in writing of the author or the publisher.

Printed in 2021.

Printed by: Innovariant Ltd., H-6750 Algyő, Ipartelep 4.

ISBN 978-963-306-803-8 (printed)

ISBN 978-963-306-804-5 (pdf)

ISSN 0133-4239 (Print)

ISSN 2677-1268 (Online) 
Table of contents

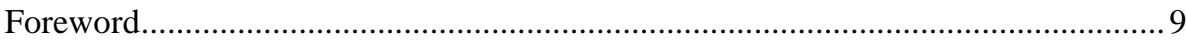

Sándor Szeverényi

Notes on Nicolaes Witsen and his Noord en Oost Tartarye. 11 Rogier Blokland

Undiscovered treasures: From the field research archive to the digital database......27 Beáta Wagner-Nagy, Chris Lasse Däbritz, and Timm Lehmberg

On the language use of the first Finnish medical text 45

Meri Juhos

Sajnovics, the responsible fieldworker 55

Sándor Szeverényi

The life and work of the Saami theologian and linguist: Anders Porsanger 71

Ivett Kelemen

The use and semantics of the Northern Mansi diminutive -riś $r \partial s$ ś 81

Bernadett Bíró

The event of "giving" and "getting" in Siberian Uralic languages 99

Katalin Sipöcz

A word-formational approach to neologisms in modern Northern Mansi

Susanna Virtanen

Word and stem repetitions in the heroic epic songs collected by Antal Reguly ..... 131 Mária Sipos

The use of body part terms in expressing emotions in Udmurt 149

Rebeka Kubitsch

The characteristics of responses given to compliments in Udmurt 173

Zoltán Németh

On some Chuvash-Mari shared lexemes and Agyagási's "Late Gorodets" hypothesis .. 185 Christopher Culver 
“Сувениры Севера" Minority identity and discourse. Representation of indigenous minorities of Northern Russia in the digital media. The case of Dudinka ........... 201 Zsuzsa Várnai and Ágnes Hámori

Reconsidering the Nganasan vowel system 229 László Fejes

New aspects in the study of Mari, Udmurt, and Komi-Permyak: The Typological Database of the Volga Area Finno-Ugric Languages 255 Erika Asztalos, Nikolett F. Gulyás, Laura Horváth, and Bogáta Timár Ethnosyntax in Siberian Uralic Languages (a project report) 275 Bernadett Bíró, Katalin Sipöcz, and Sándor Szeverényi 


\title{
Sajnovics, the responsible fieldworker
}

\author{
Sándor Szeverényi \\ University of Szeged
}

\section{Introduction}

The birth and reception of the Demonstratio has been already examined from many points of view, but it has largely remained within the linguistic discourse. In particular, recent works (e.g. Aspaas and Kontler 2015 and 2019, Kontler 2011 and 2013, S. Varga 2005) have explored the origins and reception history in a broader context, not only in the context of historical linguistics, but also the political, cultural and social background of the 18th century, and, on the other hand, by analyzing new sources, the genesis story has become more reconstrable (cf. Éder 2014, C. Vladár 2016, 2017, and relevant parts of Aspaas's work cited above); even the history of science is discussed from the astronomical point of view as well (e.g. Hansen and Aspaas 2005, Aspaas 2012).

But, there is still a question that arose at most peripherally regarding the reception of Sajnovics's work, and the simplest way to put it is what Sajnovics (and Miksa Hell) thought about the Lapp/Saami people. We do not know much about Sajnovics's relationship with them, how he worked with them, how many informants he worked with, and how exactly he collected his linguistic data from them. Did he consider his direct, human relationships important, or did he only consider Lapps as his research subjects? In brief, what type of fieldwork did Sajnovics do - if he did any at all? All these questions are hardly answered by Sajnovics and Hell themselves - and that is why there is no exact answers in the literature, but this silence can be telling and suggestive. The researcher inevitably moves to more unfirm ground: s/he is forced to reconstruct.

Why are these questions so relevant? Because 18th century ethnographic, anthropological, and linguistic fieldwork was in its infancy in the mid-18th century (or even non-existent), the description of the circumstances and the evolution of methodology can be traced back to the mid-19th century, and even more so to the last decades of the 19 th century.

The afterlife of Demonstratio is notoriously noisy, because of the fact that the Lapps are relatives of the Hungarians - although Sajnovics limited the genetic relatedness to the language (or the starting point was the language in his explanation). This northern relationship was very far from the origin of its supposed Hungarian DOI https://10.14232/sua.2021.54.71-79 
historical consciousness and folk tradition. We can also say that Sajnovics did not take into account factors outside the language, because he could not do it - even those that might have been considered national characteristics in the mid-18th century.

Sajnovics's work is pioneering in many ways. A forerunner of comparative historical linguistics (Hegedüs 2003: 14), he has long been known and acknowledged in the history of linguistics (e.g. Robins 1999: 189, Campbell 2002: 86, 90, Campbell 2016, most recently Klein et al. 2017: 1, 172). Every pioneering work is characterized by its opposition to the norm of its age: something unexpected, unusual, new is associated with a discovery. For Sajnovics, this meant that in order for the Demonstratio to be born, he had to do things (and at the same time ignore many factors) that were unusual by the standards of the age. The most important of these (apart from the narrower methodological observations now) are as follows:

(a) Sajnovics was the first Hungarian who visited an area of a "primitive" or "exotic" people that is not supposed to be a relative of the Hungarians. Before Sajnovics, as far as I know, there was no work in which the author compared language material collected from an indigenous people with his mother tongue for the sake of ignoring their contemporary civilization and culture. Campbell also notes (Campbell 2016: 252) that linguistic fieldwork and the comparative historical method were first combined in Sajnovics' work - he was the first scholar to do fieldwork for linguistic and comparative research.

(b) The aim of Sajnovics's work - as opposed to, for instance, that of the missionary Jesuits and his comrades - was not to map the language but to compare it with his own native language. But his analysis could not be independent of his own identity. Contemporary scholars, missionaries, or those whose work served as antecedent either worked from written materials or by collecting materials "in the field" through learning the language, did not have to deal with defining their own (linguistic or ethnic) relationship with the people they studied.

(c) In Sajnovics's work, a language, a culture, and a people appear to be related to the Hungarians, which in every respect is perceived and appreciated as foreign when compared to the Hungarian folk traditions, historical traditions, and in fact, the language. And Sajnovics does not consider it as a problem.

Beyond that, it must be mentioned that these questions and findings cannot be independent of the activity of Maximilian (Miksa) Hell. Recently, more and more works have been and are being published (e.g. Aspaas 2012, Vladár C. 2016, 2017), which prove that Hell played a more significant role in the development of the Demonstratio's concept than had been previously thought. So now, when I mention Sajnovics, Miksa Hell's name could be added almost always, with just a little exaggeration. 


\section{What, how and from whom did Sajnovics and Hell collect materials?}

The names of Sajnovics and Hell appear in hardly any history of anthropological research, which is not a coincidence, since it basically dates from the Enlightenment, and also justifies the fact that their ethnographic collections were not published in the end. Sajnovics, a pioneer in linguistic fieldwork, is hardly ever mentioned. We know that Miksa Hell, in his planned but unpublished three-volume work, Expeditio Litteraria, would have devoted a separate section to the ethnographic description of the Lapps (Aspaas published its summary in English in 2012; in Hungarian, see Sajnovics 1994). At the same time, the lack of information about the Lapp people in the Demonstratio is in line with the purpose of their work: they focused mainly on the language, not to describe it primarily, but to compare it with Hungarian. But Sajnovics also provides very little information on the methodology and how he proceeded, and only in Chapter 3 does he write about it in a few paragraphs, and in the remainder of the subsequent chapters we can only make inferences about working conditions. According to these remarks, Sajnovics had his own collected language material, but in Chapter 4 he only writes about Porsanger's use of Leem's dictionary, not what happened to his own notes, how extensive they were, and what they were about. In Chapter 3, he also describes how he listened to the Lapps talk. Exactly when, how many times, and under what circumstances he did so is not clear from his diary. $\mathrm{He}$ mentions two specific cases there, but one of them was a Karelian speaker he met in Mauersund. The other case, when he came from the mountains with Lapps and asked for words in the presence of Hell and with the help of an interpreter, was essentially that part of the vocabulary that we call basic vocabulary. He also mentions that "I repeated this often", and that there were "speakers of different dialects on the island", meaning that meetings of this kind took place several times. Although he does not elaborate on the details of this, many have already stated that he was also a pioneer in his method (e.g. Stipa 1990: 210).

As I mentioned before, in the history of comparative linguistics in Hungary, there is no activity similar to Sajnovics's. Until the end of the 18th century, language comparisons were typically not based own collected language materials but on the vocabularies and dictionaries collected and published by other scholars and travelers. This was applied in particular to the "holy languages", especially the Hebrew language. Before Hell and Sajnovics's expedition in 1768, no one had traveled to the "East" or North to document largely unknown languages with the aim of investigating linguistic "kinship". Furthermore, it is also well known that the Hungarian language was dealt with mostly by foreigners rather than Hungarians (Hegedüs 2003). In the Hungarians' consciousness of their origins, as reflected in Hungarian chronicles, 
language plays an inherently central role: it was not even mentioned that the languages of the Hungarians and the Huns are different. Julianus found Hungarians and not the relatives of Hungarians called Hungarians, who spoke different languages and had different lifestyles. The concept of the Caucasus homeland in the mid-18th century was also based on the similarity or identical nature of the languages spoken. The place called "Magyar(vár)" (Madschar) was assumed, which meant that there had to be Hungarians there. But the search for the Caucasian and other eastern homelands did not really begin until a few decades later, in the first half of the 19th century. Thus, attempts to find languages related to Hungarian the language purely until Sajnovics's time were based solely on sources collected and published by others, who were typically not Hungarians. We can mention here Martin Vogel of Germany, Markus Wöldike of Denmark, Philipp von Strahlenberg of Sweden - whose works were also used by Sajnovics.

It is clear from the Demonstratio that Sajnovics and Hell also had extensive knowledge of the research into the Lapp language. However, in addition to these passages, Sajnovics hardly mentions anything about the Lapp people in his Demonstratio, not even his own personal relations with any of them. He is not very wordy anywhere else either. His diary's description of the period in Lapland is recitant, focusing primarily on his work in astronomy and his local, rather official, human relationships. He rarely writes about the Lapps in his diary (Lakó 1973: 3738, Kisbán 1942: 34). In his entries of September 28 and October 6, 1768, he mentions only concrete experiences with the Lapp people. Shortly after his arrival in Vardø, he gives an objective description of their appearance, and his later entry similarly describes the living conditions of the Lapps (and/or Finns) (Sajnovics 1990: 67-68, 70). In addition, he gives a brief description of the Lapp people in a few letters. No new sources are mentioned in recent literature - that is, in fact, he writes about very few personal experiences in his writings. In his letter to Miklós Benkő, dated April 5, 1769, he gives the most detailed description of the Lapp people: "I have not yet mentioned the Lapps, let us say a few words about them" (Sajnovics 1990: 223), and then we get some information about the appearance and lifestyle of the Lapps. All this is assessed by future generations as "Sajnovics's interest in the Lapp language [which] arose at the same time as the ethnographic interest in the Lapps" (Lakó 1973: 47), for which, however, no direct evidence is found in Demonstratio. Knowing what Sajnovics's task was, the direction of the progression may have been exactly the opposite.

All in all, it is not clear what kind of relationship Sajnovics had with the local Lapps. Anders (Biret-Ánde) Porsanger (1735-1780) was undoubtedly the most important Saami person, but Sajnovics worked with him only on his journey back to Copenhagen. Porsanger was not a typical Saami, in the sense that he was no longer 
simply the son of a people: he was a Saami native speaker and the first educated Saami, who studied theology. Porsanger became assistant to Knud Leem - he did not have anyone to follow in his footsteps for a long time. At the same time, Sajnovics was not surprised by this:

"The memory of the tiring journey was immediately swept away by the sincerest sight that filled him, realizing how close he was to his Lapp people and the Hungarians, though he had long known this excellent belief, and other educated people throughout Denmark and Norway, even from historians. In addition, he exalted the magnificent Divine Providence in his cause, and he alone attributed it, unlike the domestic custom, educated and ultimately capable of taking on this great task and earning immortal merit in his country" (D34-35, emphasis added).

He met and worked with Porsanger in the spring of 1770 after returning from the north. According to his diary, they sometimes had lunch together (he mentioned two such events) and once mentioned that Porsanger was ill. Porsanger was also influenced in his work by Sajnovics: later he wrote a Saami grammar himself, although it was not published and the manuscript was lost (Martinussen 1992: 43-59). The question is how much Porsanger's personality influenced Sajnovics' relationship with the Lapps. Little is known about this. Sajnovics's comment "unlike the domestic custom" indicates that Sajnovics was aware that Porsanger had an unusual career path. It is probable, however, that for Sajnovics this was still natural: the notion of nation did not depend on the language and/or the language and culture of the various ethnicities living in the nation, but on the structure of the nation.

At the same time, there is no doubt that Porsanger faced many difficulties in his studies and work until his death, which is basically the result of discrimination against the Saami (Holdvangen et al. 2000: 35, Kelemen in this volume). The question is whether these discrimination phenomena may have been encountered by Sajnovics during their journey, and if so, whether they had been detected and appreciated at all.

In the Demonstratio, Sajnovics does not analyze his collected material but rewrites Leem's Danish-Lapp dictionary by adding Hungarian equivalents to it (cf. Campbell 2016: 252). Porsanger also participated in the work on the dictionary as Leem's assistant, and this was the main reason that he became Sajnovics's assistant. Sajnovics in the Demonstratio does not give details of what the material he collected from the Lapps was exactly like and what it consisted of. From this point of view, we could even say that because of the language comparison, he did not need to travel so far north and probably would have achieved the same results if he had worked with Porsanger in Copenhagen. Also, the word queries described at the beginning of the 
Demonstratio seem more like getting acquainted with the language than a real collection of material.

Although Sajnovics does not say anything about his Lapp materials, he explains why he does not use it, namely, because of the lack of its verifiability (D55, Sajnovics 1994: 59): “in the Elenchus I included no Lappish words that are absent from Leem's Nomenclator, and no Hungarian words that are not in the Molnár's Hungarian dictionary either. All this in order to prevent anyone from believing that I am quoting Hungarian or Lappish words in bad faith to increase the catalog." This projects the image of the responsible fieldworker far into the future: he wants to prove a kinship between two languages that can be verified by others, but there was no other way to do this at the time. However, posterity regarded it as a shortcoming, for example, Zsirai (1994: 497) commented as follows: "It is far more regrettable that Sajnovics, by leaving his Hungarian language unexploited and providing opportunities for field studies, limited himself to written sources". What is more typical is that Sajnovics's picture of fieldwork in Vardø - why else would he go there? - proves the kinship, and in Copenhagen th e work is "only" written. This is confirmed by quotes from early literature, such as the following:

"He came in contact with mountain ranges from a distance of ten miles, via Sajnovics Daass, and asked them about the names of the so-called ancient concepts common to all peoples. This process added valuable elements to his vocabulary. This way, once again, he became possessed of many word similarities. His comparative vocabulary was now quite authoritative, with the help of his mountain, he could continue to observe phonetic, morphological and later syntactic differences. In fact, he has already been through the exhausting work of collecting material. Now he felt he could begin to summarize the results of his mountain research." (Kisbán 1942: 37)

It is quite clear that in reality the causal relationships were different.

\section{Sajnovics's method}

Based on the Demonstratio and Sajnovics's diary, the method of language documentation was as follows:

(1) Comparison of sounds. It is not clear to what extent this meant learning the language and how many notes it involved. As he writes, "while I was listening to their conversation", "we didn't understand the words", but by "sound" they were sure that the two languages were "identical" (D22, 35).

(2) Using Leem's Nomenclator. He used Leem's work as a point of reference. Hell sat beside him to help, they browsed through the Lapp words in Nomenclator, 
matching the Danish and Latin meanings, and checking to find Hungarian words with similar meanings and sounds. Sajnovics writes that this was a very slow and tiring task (Sajnovics 1994: 36).

(3) "Interviews". In addition to this, Sajnovics and Hell constantly gather material from Lapp speakers, but the amount of material and the frequency of interviews can only be guessed. Basically words (and to a lesser extent texts) were queried, thematically grouped, focusing on the basic vocabulary. As mentioned above, their quantity and quality are hard to guess. For example, the remark that "I myself have experienced and Mr LEEM explains in detail that the Lapps of Finnmark have different dialects" (D52) may indicate a very rich, diverse set of direct language skills. This is also referred to in the note "I learned from living Lappish speech" (D40).

There are two notes regarding the size of the material: "And while they are large in number, it will be much larger if I publish the rest of my notes..." and " [e]very time I scroll through my manuscripts, I always find new and new Lappish words” (D80), but "I did not understand the Lapp speakers" (D13).

(4) Compiling Nomenclator with Kauriing. He had to make Nomenclator selfexplanatory, since it was published in Danish, and the Latin index was incomplete.

(5) Using Leem's Grammar with Kauriing. Following the glossary, he became familiar with grammar.

(6) Porsanger in Copenhagen, Leem's dictionary. Clarifying all of these, but only comparing them with verifiable - that is, previously published - Lapp materials.

\section{The Lapps of the 18th century: Situation, documentation, information}

Sajnovics's image of Lapps was also influenced by what kind of knowledge he had in advance. It is clear that the Lapps were a well-known population in Europe by the mid-18th century, and much of the available literature was accessible to Sajnovics and Hell, and he listed it himself in the Demonstratio.

The Saami lexicography was fundamentally different from that of other European languages, and it was much more "international" than the lexicography of Finnish (Considine 2017: 169): the most northerly living nation with no cities or universities. Northern Saami literacy began in the mid-17th century. As it is the case with many indigenous peoples, the first texts were made available thanks to missionary activity for the Saami. The earliest Saami texts are from Nicolaus Andreae from 1619 (Piteå, northern Sweden). The first book (Swenske och Lappeske ABC-book) was published in 1638, and then again in 1640, followed by the Manuale Lapponicum in 1648. In 1643 Johan Tornaeus received from the Swedish state the task of translating Swedish church texts into Saami. His work was based on the Swedish versions of North Saami and aimed to create a standard. Tornaeus was helped by speakers of various Saami 
dialects to set this certain standard. The collection of religious texts with nearly a thousand pages was based on the Torneå Saami, of course. A major change took place in the early 18th century, mainly due to the activities of Knud Leem. Most of Leem's works were already known to Sajnovics: Leem published the first grammar in 1748, and the first dictionary in 1756 and 1768. This was the basis of Sajnovics's comparative work. Leem's activities were made possible by the influence of German Pietism. from the early 1700s, and he founded his school in 1716, where he also taught and where later Porsanger became his student.

The first Saami texts (Røros Saami) were written around 1750 in Denmark, with which Norway formed a union at the time. At the same time, it was enacted in 1774 that the language of instruction for Saami children should be Norwegian (Korhonen 1981: 56). The views of Norvegians on the Saami language were reflected in their views on the Saami people and culture. Thus, in the introduction to Fjellström's Grammar (1738a), where the Swedish author states that the Saami language is spoken by an unfriendly and uneducated people who have fallen into dialects due to irregular commuting and have lost their regularity with other languages (Fiellström 1738a: 8, cited in Hovdhaugen et al. 2000: 35). Sajnovics used Fjellström's work a lot, but he did not refer to this passage, but quoted strictly phonetic and grammatical descriptions only. It is not clear, however, which of Fjellström's works was published in 1738: a dictionary or a grammar. In the 1994 edition of the Demonstratio, it is assumed that he used the dictionary, at least the grammar is not mentioned in the appendix (Sajnovics 1994: 131), but due to the high number of grammatical references, the Grammar is also mentioned by Sajnovics (D13, Sajnovics 1994: 29).

Sajnovics might have known the views of other scientists, who, however, were less negative and took other aspects into account. For example, the Swedish Ganandrus / Ganander Grammar (1643), also used by Sajnovics, in which the author believed that Saami is a very ancient language, like Hebrew. According to Ganander, Saami, along with Finnish and Estonian, was one of 70 languages created after the confusion of the tongues at the Tower of Babel. Leem, the author of Sajnovics's most important source, also speaks of Saami in his preface to Grammar (1748), summarizing what was thought of Saami at that time: "an absurd, wild, and confused language with no rules for vocabulary, inflexion and the like. Others imagine this is a random mixture of many languages" (Hovdhaugen et al. 2000: 35). However, Leem disagreed, saying that Saami was not just a very old language that had long been used, by people "who had the same faith and religion as us, the same God and they serve a king with us, we live in the same kingdom" and it is "an interesting, accurate and rich language" (Leem 1748, Preface, quoted by Hovdhaugen et al. 2000: 35).

There is little work reflecting on the 18th century European awareness of the Lapps. There is no doubt that the Lapps, as indigenous native peoples, were 
considered as exotic as other native peoples outside Europe. However, due to their geographical proximity, relatively few modern myths were woven around them (cf. Vértes O. 1938). What was the image of Lapland in 18th century Europe? In addition to the ancient authors (Tacitus, Procopius), the works of Swedish Catholic bishop Olaus Magnus (1492-1557), Carta marina (1539) and Historia de gentibus septentrionalibus (1555), and the influence of Johannes Schefferus' Lapponica (1673) made the Lapps known in Europe. Schefferus' work was immediately translated into English (1674), German (1675), French (1678), and Dutch (1682). It should be added that Schefferus himself never went to Lapland. He met most Saami at the University of Uppsala (Rydving 2010, cited by Nordin and Ojala 2015: 117) and in the urban market (Löw 1956: 16, cited by Nordin and Ojala 2015: 117), and it is known that in the 17th century the Saami lived in greater numbers in central Sweden, meaning people did not have to travel to northern Lapland meet them. Schefferus acquired geographic, religious, economic, and cultural knowledge from them. Illustrations of the volume became well-known throughout Europe, defining the image of Lapland in Europe. (Thon (2016) gives an excellent interpretation of 17th-century Saami iconography.)

If we are to draw an 18th century European image of Lapland, even though we go back to the beginnings of modern anthropology, we find few handholds, and Sajnovics makes no mention of general works in this field. In relation to native peoples, "until the birth of anthropology in the nineteenth century, two stereotypes of opposite ends emerged" in philosophical thinking, dating back to the 16th century (Vargyas 2009: 3). Citing Vargyas' paper (2009), one view is related to Hobbes, Hobbes saw the "state of nature" as the rule of brutal violence, "where every man is Enemy to every man", which he called for the eradication of tyranny, the symbol of the biblical Leviathan. "The life of man, solitary, poore, nasty, brutish, and short", and under these circumstances there is no place for diligence, because its fruit is uncertain; there are no means of transporting powerful objects to and fro, no knowledge of the earth, no time, no arts, no literature, no social contact, and worst of all, eternal fear, the danger of violent death (Hobbes 1970 [1651]: 109). Rousseau and, generally, the "good, noble savage" of the French philosophers, argued that "nature made man happy and good, but that society depraves him and makes him miserable", and "born free and everywhere he is on the chain" (Rousseau 1972 [1762]: 6, 22). These idealized "wild people" provided "ammunition" to pillory western society. Whether Sajnovics read or indirectly influenced the work of Rousseau or Voltaire and Hobbes is unknown. Sajnovics was primarily a naturalist and, moreover, a Jesuit, but in the case of Hell, the issue was more complicated because of his active relationship with Jesuit historians. And the French philosophy of history began to have an impact after the birth of the Demonstratio, even more so in Hungary, and this will be particularly 
important in judging the kinship, of languages and nations especially as a result of the work of the prominent poet and playwright of the Englisghtenment, György Bessenyei. The first wave of the influence of French world history dates from 1760 to 1770 , the second wave from 1770s can be hallmarked by Bessenyei's historical works (see e.g. Penke 2000).

Vértes O. wrote in her classic 1938 work about the appearance of Finno-Ugric peoples, including the Lapps, in French literature. As she mentioned, among the Finno-Ugric peoples, the literature on the Lapps was the most extensive, and the interest was general. However, they could not compete with the popularity of nonEuropean peoples in terms of "being fashionable".

The anthropological peculiarity of the Lapps appeared already in the 17th century. The term "race" was applied to human groups by François Bernier, a French physician and traveler. He was the first who visited Poland, Egypt, and India (Vermeulen 2015: 367). In his short article in the Journal des Sçavans, he (Bernier 1684: 148) distinguished four or five races: "the first being Europeans, Egyptians, the Hindus, and American Indians; the second is Africans; the third is the Chinese and the Japanese; and the fourth is the Lappish. The classification was geographical and somatic: based not only on skin color, but also on the features of the face, such as the shape of the nose, lips, teeth, and hair. Bernier admitted that he knew almost nothing about the Lapps (his experiences with the African people in the Turkish and Arabic slave markets). Its species classification was a judgment of value" (Vermeulen 2015: 367). This example also shows that the Lapps were known in Europe, even if they had not been seen.

\section{Identity and language}

At the turn of the 18th and 19th century, György Bessenyei - and many of his contemporaries - simply overlooked the question of language and kinship. Language was not a "sign of nation". The instrumental conception of language was general: the goal was the common good, which could be achieved through the dissemination of science, and the key to the dissemination of science was language, that is, language was a means of achieving the common good and not the nation. This is illustrated very well by, for example, the reception of Joseph II's Language Decree of 1784: in 1784, 37 counties voted for Latin, and only 20 for Hungarian (Soós 2005), for example, Ferenc Kazinczy also supported the decree. Let there be no misunderstanding, at that time Kazinczy was "extremely interested in the Hungarian language as a writer, but not as interested in the language of the nation" (Bíró 2010: 69). So what did one need to do with one's northern relatives to be acceptable? To confer glorious qualities on them. Just as András Dugonics did in his novel Etelka. If they are to be depicted in a 
negative color, the negative "moral" qualities must be emphasized, as László Perecsenyi Nagy did in 1804 in his work, Orithia (see Szeverényi 2002).

Previously, little attention was paid to the role played by the mother tongue and its history in the formation of the national identity. The situation of the Hungarian language and the development of the concept of nation can be traced most closely to the evolution of literature, because "there is also a significant chapter of another great story, the history of the concept of nation" (Bíró 2005: 582). From this point of view, the time of the Demonstratio is key. In the second half of the 18th century, earlier Hungarian concepts of community underwent a transformation. In pre-18th century Hungary, three concepts of nation coexisted (e.g. Bíró 2005; Bíró 2010): on the one hand, Hungarians' consciousness as a territorial community concept was linked to the institution of the kingdom, the community of Hungarians, regardless of the language. The natio Hungariae, which is organized in the corporate sense of the Order, provides conceptual equality and communication. This was conditional on belonging to the country's privilegedand "representative" political community (communitas regni) and "body", but not to language. The order's solidarity with the court was for the most part, and for a relatively long time, stronger than the other bonds. The third concept is language- and culture-based identities. The latter intensifies in the second half of the 18th century, at the expense of the previous two but in fact only appears in the generation following Bessenyei's, relatively suddenly. This is also evident in Kazinczy's change of mind in just ten years: "In 1780 he looked at the language of Prešov/Eperjes with no particular emotion, and was not annoyed by the miserable fate of the Hungarian language, but by the fact that he had no opportunity to practice French. In ten years, however, in 1790, non-native speakers of Hungarian who would not want to learn Hungarian are threatened with hunger" (Bíró 2005: 592). S. Varga's (2005) paradigm division in the evolution of Hungarian literature corresponds to this three-tiered concept of nation: community of traditions, union of states, and community of origin. Bessenyei and his contemporaries, according to the community of origin, reject linguistic affinities, because if the language is added to character traits, it also expresses the national character: "the affinity with the inferior character of the speakers of related languages is inevitable" (S. Varga 2005: 244).

Sajnovics's identity was far from the linguistic-cultural concept, he was a real Hungarus. The way he treated the Lapps and the Lappish relatives is entirely consistent with this. So, not surprisingly, the most part of the negative reviews of the Demonstratio was born later, from 1790's.

\section{Conclusion}

The Demonstratio could not be the product of any other time - at least in this form before the third quarter of the 18th century. If the Venus retreated either sooner or 
later before the Sun, it is unlikely that the expedition would have taken place. Certainly not a few decades earlier, because, in the absence of relevant language data, the idea of a northern kinship had not yet arisen. Furthermore, in Josefinism, linguistic-cultural identity was so powerful that it might not be a coincidence that a few decades later, the indigenous and relatives were searched in the East rather than in the North. So we return to the original question: how did Sajnovics look at the Saamis? Let's see what we know:

(1) Sajnovics certainly worked with Saami speakers, typically in the presence of Hell and with the help of an interpreter. For this reason, no deeper personal contact with the locals could be established. The exception was Porsanger, who was not a typical member of the Lapp community. His comments suggest little about this. In his diary, well-known letters, and in the text of the Demonstratio, it is more likely that he did not maintain an active relationship with the Lapps. He does not detail his relationship with Porsanger, he sees a European worker, a member of the Danish state and not just a native person. Sajnovics has no subjective comment about the Lapps. This neutrality corresponds to the consciousness of the Hungarus.

(2) The only Saami to qualify was Porsanger, who is considered to be the first university educated Saami person and lived in Copenhagen. The work was done on the way back from the expedition and in Copenhagen - when Sajnovics, more or less, no doubt - had his own direct experience of the Saamis.

(3) His method of documentation demonstrates a sense of responsibility.

\section{References}

Aspaas, Per Pippin 2008. Maximilian Hell's invitation to Norway. Comm. in Asteroseismology, 49: 10-20.

Aspaas, Per Pippin 2012a. Maximilian Hellin ja Johannes Sajnovicsin "Expeditio litteraria ad Polum arcticum" ja suomalais-ugrilaisen kielentutkimuksen synty. In: Osmo Pekonen and Johan Stén, eds. Lapin tuhat tarinaa. Ranua: Mäntykustannus 65-88.

Aspaas, Per Pippin 2012b. Maximilianus Hell (1720-1792) and the eighteenthcentury transits of Venus. https://munin.uit.no/handle/10037/4178. Date of access: August 15, 2020

Aspaas, Per Pippin and László Kontler 2015. Before and after 1773: Central European Jesuits, the politics of language and discourses of identity in the late eighteenth century Habsburg Monarchy. In: Gábor Almási and Lav Šubarić (eds.), Latin at the crossroads of identity: The evolution of linguistic nationalism in the Kingdom of Hungary. Leiden and Boston: Brill, 95-120. 
Aspass, Per Pippin and Kontler, László 2019. Maximilian Hell (1720-92) and the ends of Jesuit science in enlightenment Europe. Jesuit Studies, Volume 27. Leiden and Boston: Brill

Bíró, Ferenc 2005. Nyelv, „tudományok”, nemzet [Language, “sciences”, and nation]. Holmi, 17: 580-594.

Bernier, François 1684. Nouvelle Division de la terre par les différentes espèces ou races d'hommes qui l'habitent. Journal des Sçavans, April 24: 85- 89.

C. Vladár, Zsuzsa 2017. Hell mint nyelvész: A Kar-jelia etimológia és a kínai hasonlítás példája [Hell as a linguist: the Kar-jelia etymology and the example of Chinese comparisons]. In: Forgács, Tamás, Németh, Miklós and Sinkovics, Balázs (eds.). A nyelvtörténeti kutatások legújabb eredményei IX [The most recent findings of historical linguistic research, vol. 9]. Szeged: Szegedi Tudományegyetem, Magyar Nyelvészeti Tanszék, 337-350.

C. Vladár, Zsuzsa 2016. Valójában ki a szerzője a Demonstratiónak? [Who is the author of Demonstratio really?] Magyar Nyelv, 112: 316-324. DOI: 10.18349/MagyarNyelv.2016.3.316

Campbell, Lyle 2002. The history of linguistics: In: Aronoff, Mark and Rees-Miller, Janie (eds.). The handbook of linguistics. Oxford: Wiley-Blackwell, 81-104.

Campbell, Lyle 2016. Language documentation and historical linguistics. In: Andrea L. Berez-Kroeker, Diane M. Hintz and Carmen Jany (eds.), Language contact and change in the Americas: Studies in honor of Marianne Mithun. Studies in Language Companion Series 173. Amsterdam and Philadelphia: John Benjamins, 247-272. DOI: 10.1075/slcs.173.11cam

Considine, John 2017. Small dictionaries and curiosity: Lexicography and fieldwork in post-Medieval Europe. Oxford: Oxford University Press.

Éder, Zoltán 1999/1976. Újabb szempontok a „Demonstratio” hazai fogadtatásának kérdéséhez [New aspects of the reception of Demonstratio in Hungary]. In: Éder, Zoltán. Túl a Duna-tájon [Beyond the Danube region]. Budapest: Mundus Magyar Egyetemi Kiadó, 47-61. (First edition: Beiträge zum IV. Internationalen Finnougristen kongress II. Istituto Universitario Orientale, Napoli 1975. 3-21.)

Éder, Zoltán 2014. Sajnovics Demonstratiójának első recenziója: „Viennensis recensitor opusculi mei Hafniae editi" [The first review of Sajnovics's Demonstratio: "Viennensis recensitor opusculi mei Hafniae editi"]. Magyar Nyelv, 110: 85-94.

Fjellström, Petrus 1738. Dictionarium Sueco-Lapponicum, eller en Orda-Bok. Stockholm: Literis Joh. Laurentii Horn.

Fjellström, Petrus 1738. Grammatica Lapponica. Stockholm: Literis Joh. 
Hám Sándor 1889. Sajnovics János élete és Demonstratioja [János Sajnovics's life and Demonstratio]. Esztergom.

Hansen, Truls Lynne and Aspaas, Per Pippin 2005. Maximilian Hell's geomagnetic observations in Norway 1769. Tromsø Geophysical Observatory Reports. No. 2. Tromsø: University of Tromsø.

Hegedüs, József 2003. Hiedelem és valóság [Beliefs and reality]. Budapest: Akadémai Kiadó.

Hobbes, Thomas 1970[1651]. Leviatán, vagy az egyházi és világi állam anyaga, formája és hatalma. Budapest: Helikon Könyvkiadó

Hovdhaugen, Even, Karlsson, Fred, Henriksen, Carol and Sigurd, Bengt 2000. The history of linguistics in the Nordic countries. Helsinki: Societas Scientiarum Fennica.

Kelemen, Ivett 2018. Knud Leem, a 18. századi számi lexikográfia úttöröje: Vázlatok a Lexicon Lapponicum Bipartitum történetéröl [Knud Leem, a pioneer of 18th century Sami lexicography: Notes regarding the history of Lexicon Lapponicum Bipartitum]. FUD 25: 99-108.

Kisbán, Emil 1942. Tordai és kálózi Sajnovics János, 1733-1785 [János Sajnovics of Torda and Kálóz, 1733-1785]. Debrecen: [s.n.]; Budapest: Csáthy.

Klein, Jared, Joseph, Brian, and Fritz, Matthias (eds.) 2017. Handbook of comparative and historical Indo-European linguistics. Handbücher zur Sprach- und Kommunikationswissenschaft 41.1. Berlin and Boston: De Gruyter Mouton.

Kontler, László 2011. The Lappon, the Scythian and the Hungarian, or our (former) selves as 'others': Philosophical history in eighteenth-century Hungary. Encountering Otherness. In: Abbatista, Guido ed. Diversities and transcultural experiences in early modern European culture. EUT, Edizioni Università di Trieste, 131-145.

Kontler, László 2013. Politicians, patriots and plotters: Unlikely debates occasioned by Maximilian Hell's Venus Transit Expedition of 1769. The Journal of Astronomical Data, 19(1): 83-93.

Korhonen, Mikko 1981. Johdatus lapin kielen historiaan. Helsinki: SKS.

Lakó, György 1973. Sajnovics János. Budapest: Akadémiai Kiadó.

Löw, Bengt 1956. Johannes Schefferus och hans Lapponia. In Johannes Schefferus, Lappland. Uppsala: Almqvist \& Wiksell, 9-23.

Martinussen, Bente 1992. Anders Porsanger: Teolog og språkforsker fra 1700-tallets Finnmark. Nordlyd: Tromsø University Working Papers on Language and Linguistics 18: 15-59.

Nordin, Jonas M. and Ojala, Carl-Gösta 2015. Collecting Sápmi. Early modern collecting of Sámi material culture. Nordisk Museologi 2015/2, 114-122. 
Penke, Olga 2000. Filozofikus világtörténetek és történetfilozófiák [Philosophical histories of the world and philosophies of history]. Budapest: Balassi.

Robins, Henry Robert 1999. A nyelvészet rövid története [A short history of linguistics]. Budapest: Osiris - Tinta.

Rousseau, Jean-Jacques. 1972 [1762] A társadalmi szerződés. Bukarest: Kriterion (,Téka”).

Rydving, Håkan 2010. Samiska överhetspersoner i Sverige-Finland under 1600talet." In Else Mundal and Håkan Rydving (eds.). Samer som ”de andra", samer om "de andra. Identitet och etnicitet $i$ nordiska kulturmöten. Umeå: Umeå universitet, 259-265.

S. Varga, Pál 2005. A nemzeti költészet csarnokai [Halls of national poetry]. Budapest: Balassi.

Sajnovics, János 1990. Sajnovics János naplója 1768-1769-1770 [János Sajnovics’s diary, 1768-1769-1770]. Budapest: ELTE.

Sajnovics, János 1994. Demonstratio. Budapest: ELTE.

Soós, István 2005. II. József nyelvrendelete és a „hivatalos Magyarország” [Joseph II's decree on language and the "official Hungary"]. In: Bíró, Ferenc (ed.): Tanulmányok a magyar nyelv ügyének 18. századi történetéböl [Studies on the 18th c. history of the status of the Hungarian language]. Budapest: Argumentum, 261-301.

Storm, Dikka 2009. Network of missionaries and the establishment knowledge: Creating space. In: Charlotte Damm and Janne Saarikivi (eds.) Networks, interaction and emerging identities in Fennoscandia and beyond. Tromsø, Norway, October 13-16 2009. Suomalais-Ugrilaisen Seuran Toimituksial Mémoires de la Société Finno-Ougrienne, 265: 263-284.

Stipa, Günter 1990. Finnisch-ugrische Sprachforschung. Suomalais-Ugrilaisen Seuran Toimituksia/ Mémoires de la Société Finno-Ougrienne 206.

Szeverényi, Sándor 2002. Perecsenyi Nagy László. Szombathely: BDTF.

Thon, Jahn Holljen 2016. Knud Leem's illustration of the unfamiliar. Studia IBB Philologica 61(3): 143-162.

Vargyas, Gábor 2009. A zsákmányolók képe a kulturális antropológiában [The image of the plunderer in cultural anthropology]. In: Berta Péter, ed. Ethno-Lore, 26: 207-238. http://nti.btk.mta.hu/images/evkonyv/2009/vargyasgabor.pdf

Vermeulen, Hans F. 2015. Before Boas: The genesis of ethnography and ethnology in the German enlightenment. Lincoln \& London: University of Nebraska Press.

Vértes, O. Auguszta 1938. A finnugorság felfedezése a francia irodalomban [The discovery of Finno-Ugric peoples in French literature]. Budapest: Kókai Lajos kiadása. 
Zsirai, Miklós 1937/1994. Finnugor rokonságunk [Our Finno-Ugric relations]. Budapest: Trezor Kiadó, 474-582. 